\title{
BRAIN ABSCESS FOLLOWING THE INSERTION OF SKULL TONGS
}

\author{
By John C. Hall, M.B., B.S., F.R.A.C.S. ${ }^{1}$ and David C. Burke, \\ M.B., B.S., D.P.R.M., F.R.A.C.P. ${ }^{2}$ \\ 1 Surgical Registrar, Austin Hospital, Heidelberg, Victoria, Australia; \\ 2 Director, Spinal Injuries Unit, Austin Hospital, Heidelberg, Victoria, Australia
}

Abstract. Brain abscess is an uncommon complication of the insertion of skull tongs. The two cases reported demonstrate the difficulty that may occur in diagnosis and the high mortality associated with this complication.

Key words: Brain abscess; Skull tongs.

THE conservative management of unstable cervical spinal injuries was greatly aided by the introduction of skeletal traction via head tongs, Crutchfield (I954). Complications resulting from its use are uncommon. This report describes two cases of brain abscess following the use of head tongs and emphasises the possible insidious nature of this complication and its high mortality. During the period I955-76 inclusive 490 patients managed at the Victorian Spinal Injuries Unit had head tongs inserted. The incidence of this complication during that period was therefore 0.4 per cent.

\section{Clinical Records}

Case I. A 3I-year-old man presented in 1960 with an incomplete C6 spinal cord lesion following a motor car accident. A 'superficial soft tissue infection' appeared on the right side I week after the insertion of the tongs. It apparently resolved without drainage or use of antimicrobials. Two weeks later the patient was febrile and had a severe convulsion. After carotid arteriography had demonstrated a lesion on the right side of the brain the patient was operated upon. Fifteen millilitres of pus were removed from beneath the site of the right tong. The patient subsequently died and at post mortem there was evidence of penetration of the skull by the tongs.

Case 2. $A$ 35-year-old man presented in 1975 with a complete $C_{5}$ spinal cord lesion following a motor car accident. Six weeks after insertion of skull tongs, an infected right tong site was managed by the application of Eusol dressings. The traction was removed I week later. Over the ensuing months there were episodes of headaches and 'fainting attacks' not associated with elevation of temperature or white cell count. After one episode there was a transitory facial weakness. Electroencephalograms were performed on four occasions and reported as normal. Ten months after the initial admission the patient collapsed and died of what was clinically described as a 'cardio-vascular accident'. At post mortem there was a large brain abscess underlying the right head tong site.

\section{Discussion}

In both instances the procedure was performed in antiseptic fashion. The technique of drilling into the skull was performed under direct vision with the

Address for reprints: Dr D. C. Burke, Spinal Injuries Unit, Austin Hospital, Heidelberg, Victoria 3084, Australia. 
use of guarded drill bits. Under these circumstances one might expect the inner table of the skull to remain intact. However, as both of these abscesses occurred directly beneath the skull tongs, it is untenable to assume that the route of infection was other than direct spread from the superficial wound.

Case 2 illustrates that brain abscesses may have an insidious clinical presentation. An earlier diagnosis may have been achieved, in that case, if the electroencephalograms had been followed by further investigations. It is of note that Anagnostopoulos and Gortvai (1973) found that whilst electroencephalograms correctly located three out of $\mathrm{I} 3$ subdural brain abscesses carotid arteriography demonstrated I I out of I9. Brain scans could be expected to have an even higher degree of accuracy of diagnosis.

If this complication is to be minimised then:

I. Care must be taken with regard to both the antiseptic technique and the minimal use of trauma whilst inserting the head tongs;

2. any infection at the head tong site must be treated vigorously;

3. in patients who have had head tongs inserted neurological symptoms, even with minimal clinical signs, may indicate the presence of a brain abscess, and

4. the exclusion of a brain abscess may require more than repeated electroencephalography.

\section{SUMMARY}

Two cases of brain abscess following the use of head tongs have been reported. These were the only two cases diagnosed in the period 1955-76, during which 490 patients were treated with head tongs, an incidence of 0.4 per cent. The difficulty in diagnosis and the high mortality associated with this complication are stressed.

\section{RÉSUMÉ}

2 cas d'abcès du cerveau ont été signalés après l'utilisation de pinces-vis pour immobiliser le crane. Ce furent les 2 seuls cas diagnostiqués dans la periode 1955-76, pendant laquelle 490 malades furent traites avec des pinces-vis craniennes. Nous signalons la difficulté du diagnostic et la haute mortalité associée avec cette complication.

\section{ZUSAMMENFASSUNG}

Zwei faelle von Gehirninfectionen durch den Gebrauch von Kopfzangen sind bekannt. Dieses waren die einzingsten zwei faelle diagnosen in den jahren 1955-76 in welcher Zeit 490 patienten mit Kopfzangen behandelt wurden, ein vorfall von 0.4 prozent. Die groesste Schwierigkeit liegt in der diagnose, und die hoher sterbefaelle verbunden mit dieser complicationen werden hier mit zum Ausdruck gebracht.

\section{REFERENCES}

Anagnostopoulos, D. I. \& Gortvai, P. (1973). Intracranial subdural abscess. Brit. $\mathcal{F}$. Surg., 60, 50.

CRUTCHFIELD, W. G. (I954). Skeletal traction in treatment of injuries to the cervical spine. F.A.M.A., 155, 29. 